\title{
Hayvan Islahında Güncel Bir Yaklaşım: CRISPR/Cas9 Genom Modifikasyon Sistemi
}

\author{
Fatih Bilgi, Zeynep Demirtaş, Levent Mercan*
}

Ondokuz Mayıs Üniversitesi, Ziraat Fakültesi, Tarımsal Biyoteknoloji Bölümü, 55139 Samsun, Türkiye

\section{A K A L E B İ L G İ S İ}

Geliş 21 Haziran 2016

Kabul 18 Kasim 2016

Çevrimiçi baskı, ISSN: 2148-127X

Anahtar Kelimeler:

Gen düzenlenmesi

CRISPR/Cas9

Hayvan 1slahı

Genom

Performans

*Sorumlu Yazar:

E-mail: 1mercan@omu.edu.tr

\section{Ö Z E T}

Genom modifikasyonları, verimin arttırılmasında ve hastalıklara karşı direncin kazandırılması konusunda önemli avantajlar sağlama potansiyeli içermektedir. Bireyin zaten sahip olduğu bir genin susturulmasını ya da ifade edilmesini sağlayan gen düzenlenmesi yöntemleri (gene editing) çevreyi en az etkileyerek genetik yapının geliştirilmesi konusunda önemli olanaklar sağlamaktadır. Son zamanlarda yeni genetik düzenleme yöntemleri geliştirilmiştir. Bunlar ZFN (Zinc Finger Nuclease)'ler, TALEN (Transcription Activator-like Effector Nuclease)'ler ve CRISPR/Cas nükleaz sistemleridir. CRISPR/Cas sistemi yabancı genetik materyalleri yok etmek için RNA güdümlü nükleazları kullanan bir mikrobiyal immün sistem olup, bu sistemin günümüzde hayvanlarda basit ve etkili bir gen düzenleme mekanizması olarak kullanılabilme potansiyeli değerlendirilmektedir. Bu derlemede CRISPR/Cas9 sistemi ve hayvan ıslahında kullanılabilirliği özetlenmiştir.

Turkish Journal Of Agriculture - Food Science And Technology, 4(12): 1118-1122, 2016

\section{A Current Approach in Animal Breeding: CRISPR/Cas9 Genome Modification System}

\begin{tabular}{l} 
A R T I C L E I N F O \\
\hline Article history: \\
Received 21 June 2016 \\
Accepted 18 November 2016 \\
Available online, ISSN: $2148-127 \mathrm{X}$ \\
\hline Keywords: \\
Gene editing \\
CRISPR/Cas 9 \\
Animal breeding \\
Genome \\
Performance
\end{tabular}

*Corresponding Author:

E-mail: lmercan@omu.edu.tr

\section{A B S T R A C T}

Genome modifications include potential about providing significant advantages on increasing yield performance and developing resistance to diseases. Gene editing methods that provides silencing or expressing of a gene which is an individual already has, have important potential for improving genetic structure without environmental effects. In recent times, new gene editing systems were developed. These are ZFNs (Zinc Finger Nucleases), TALENs (Transcription Activator-like Effector Nucleases) and CRISPR/Cas nuclease systems. CRISPR/Cas system is a microbial immune system that uses RNA guided nucleases for destroying genetic materials and its potential usage like a simple and efficient gene editing mechanism in animals is being evaluated recently. In this review, we summarized CRISPR/Cas9 system and its usability in animal breeding.

\section{Giriş}

İnsan nüfusunun 2050 y1lında 10 milyar olacağ öngörülmektedir. Dünya üzerindeki bu nüfus artışına paralel olarak besin ihtiyacı da artmaktadır. Geleneksel tarımsal sistemlerin bu nüfusu besleyemeyeceği düşünülmektedir (Hackeet ve ark., 2014; Hoekstra ve Wiedmann, 2014). Tarım sektöründe meydana gelen teknolojik gelişmelere rağmen dünya üzerindeki açlık son 10 yılda daha da artmış, hızla artan nüfusu beslemek için uygulanan ağır tarımsal uygulamaların çevre üzerine küresel ısınma ve kirlilik gibi olumsuz etkileri olmuştur (Eisler ve Lee, 2014).
Son yıllarda tarımda verim artışının çevreye zarar vermeden sağlanmasına odaklanılmaktadır. Hayvanların kültüre alınmasından günümüze insanlar, hayvanlardan daha fazla verim alabilmek için onların genetik yapılarını klasik ıslah yöntemleri ile iyileştirmişlerdir. Hali hazırda hayvancılıkta kullanılan moleküler islah uygulamalarının da gelecekte artacak ve çeşitlenecek tüketici beklentilerini karşılamada ve aynı zamanda değişen çevre koşullarına bağlı olarak ortaya çıkan hastalıklara karşı dirençli genotiplerin geliştirilmesinde yetersiz kalacağ öngörülmektedir. Genom modifikasyonları, verimin arttırılmasında ve hastalıklara karşı direncinin sağlanması 
konusunda önemli avantajlar sağlama potansiyeli içermektedir (Vince, 2014).

Genetiği değiştirilmiş organizmaların insan sağlığına ve çevreye yapabileceği olumsuz etkileri ve bu konudaki etiksel endişeler insanların genetik yapısı düzenlenmiş hayvanların ticari yetiştiriciliğine de olumsuz yaklaşmalarına sebep olmaktadır. Genetiği değiştirilmiş hayvanlar ile ilgili en önemli kaygıların başında bu hayvanların, birçok hücre tipinde çalışabilen ekspresyon kasetlerine sahip olmaları ve bu kasetlerin genom ile rastgele etkileşim kurma potansiyeli bulunan vektörler ile aktarılmış olmalarıdır. Bireyin zaten sahip olduğu bir genin susturulmasını ya da ifade edilmesini sağlayan gen düzenlenmesi (gene editing) yöntemleri çevreye en az zarar vererek genetik yapının geliştirilmesinde çok önemli bir potansiyele sahiptir (Hackett ve Alvarez, 2000; Hackeet ve ark., 2014).

Hayvansal üretimde genom modifikasyonları tarımsal üretimde kullanılan hayvanların bireysel verimlerinin arttırılmasının yanında insanların ihtiyaç duyduğu organların hayvanlardan sağlanmasına kadar birçok alanda kullanılabilir. Buna örnek olarak, organ nakli bekleyen bir insana ait indüklenmiş pluripotent kök hücrelerin organ gelişimini etkileyen bazı spesifik genleri susturulmuş blastokist evresindeki domuz embriyolarına enjeksiyonu ile domuzdan alınan organın insan vücudu tarafından sorunsuz bir şekilde kabul edilmesi verilebilir (Hackeet ve ark., 2014).

\section{Gen Düzenlenmesinde CRISPR/Cas9 Teknolojisi}

Organizmaların genetik yapısının değiştirilebilmesi biyoteknolojik açıdan önemli avantajlar sağlamaktadır. Son zamanlarda yeni genetik düzenleme yöntemleri geliştirilmiştir. Bunlar ZFN (Zinc Finger Nuclease)'ler, TALEN (Transcription Activator-like Effector Nuclease)'ler ve CRISPR/Cas nükleaz sistemleridir (Ran ve ark., 2013).

CRISPR/Cas sistemi yabancı genetik materyalleri yok etmek için RNA güdümlü nükleazları kullanan bir mikrobiyal immün sistemdir. Şimdiye kadar 3 farklı CRISPR/Cas sistemi keşfedilmiştir (Cho ve ark., 2013). Her sistem Düzenli Aralıklarla Bölünmüş Palindromik Tekrar Kümeleri (Clustered Regularly Interspaced Short Palindromic Repeats - CRISPR) ile bağlantılı proteinleri (CRISPR associated protein - Cas), kodlanmayan RNA'ları ve farklılaşmış tekrar eden dizileri içerir. Bu tekrar dizileri protospacer'ler olarak bilinen ekzojen DNA hedeflerinden türemiş farklılık gösterebilen kısa nükleotid dizileri tarafından ayrılmışlardır ve birlikte CRISPR RNA (crRNA) dizisini oluştururlar. Hedef DNA'nın içinde, her bir protospacer kullanılan spesifik CRISPR sistemine bağlı olarak farklılık gösteren Protospacer İlişkili Motifiler (PAM, Protospacer Associated Motives-PAM) ile bağlantılıdır (Barrangou ve ark., 2007).

Tip 2 CRISPR sistemi en iyi karakterize edilmiş CRISPR sistemlerinden biridir ve nükleaz Cas9, kılavuz RNA'ları kodlayan crRNA dizisi ve crRNA'ların farklı ünitelere işlenmesini gerçekleştiren gerekli yardımcı trans-etkinleştirici crRNA (tracrRNA)'ları içerir. Her bir crRNA ünitesi 20-nt kılavuz sekansı ve kısmi direk tekrarlar içerir (Garneau ve ark., 2010). CRISPR/Cas9'ın RNA kılavuzlu nükleaz fonksiyonu insan kodon optimizeli Cas9 ve gerekli RNA bileşenlerinin heterolog ekspresyonuyla memeli hücrelerinde yeniden yapılandırılmıştır (Cong ve ark., 2013). Dahası crRNA ve tracrRNA kimerik tekli kılavuz RNA (single guided RNA-sgRNA)'yı oluşturmak için birleşir. Cas9 sgRNA içindeki 20-nt kılavuz sekansının değiştirilmesi ile PAM sekansının hemen yakınındaki herhangi bir hedefe yönlendirilebilir (Ran ve ark., 2013).

Uygulanabilirliğinin ve tekrarlanabilirliğinin yüksek olmas1 nedeniyle Cas9 Homolog Olmayan Rekombinasyon (Nonhomologous End Joining - NHEJ) ve Homoloji Yönlendirmeli Tamir (Homology Directed Repair - HDR) genom modifikasyon yöntemleri ile düzenlenmiş spesifik mutasyonları taşıyan ökaryotik hücrelerin üretilmesinde kullanılmaktadır (Cho ve ark., 2013). sgRNA'nın ve mRNA kodlayıcı Cas9'un embriyolara direk enjeksiyonu ile bir çok modifiye allelle sahip farelerin hızla çoğalması sağlanmıştır (Wang ve ark., 2013).

Cas9 kolaylıkla 20-nt k1lavuz dizisini kodlayan yeni bir oligo çifti alınarak yeni bir DNA dizisi için de uyarlanabilir (Sanjana ve ark., 2012). Cas9 birçok hücre tipinde ve organizmada genom düzenlemesinde etkili bir biçimde çalışmaktadır. Cas9, kolay hedeflemesi sayesinde sgRNA'ların bir kombinasyonunun hedef hücrelere ortak olarak aktarılması ile birçok hedeflenen genomik lokusta aynı anda kullanılabilir (Ran ve ark., 2013).

Cas9 sgRNA üzerindeki 20-nt kılavuz sekansı ile spesifik genomik lokusa hedeflenir ancak bu hedefleme için özgün PAM sekansına ihtiyaç duyulmaktadır. Her bir Cas9 ortologu özel bir PAM sekansına sahiptir, örneğin SpCas9 5'-NGG PAM sekansina gereksinim duyar. Ayrıca hedef diziler arasındaki bölgelerin uzunluğu arttıkça istenmeyen mutasyonların gerçekleşme ihtimali ile birlikte özgün PAM dizisi ihtiyacı bu yöntemin en önemli kısıtlayıcısıdır. Hedefleme aralığı hedef bölgelerin her 8-12 bç'de bir bulunabildiği insan gibi organizmalarda önemli bir sorun oluşturmamaktadır (Oliviera ve ark., 2012).

\section{Yöntemin Uygulanması}

Cas9 nükleazın özgünlüğü sgRNA içinde bulunan 20nt kılavuz dizisi ile belirlenmektedir. Gen hedeflemesi için oluşturulan 20-nt kılavuz dizisinin seçiminde iki önemli husus vardır: 5'-NGG PAM sekansı ve hedef dışı aktivitenin azaltılmasıdır.

\section{sgRNA'nın Oluşturulması ve Aktarılması}

Kullanılacak yönteme bağlı olarak sgRNA ekspresyon kasedi içeren PCR amplikonları ya da sgRNA'yı ifade eden plazmidler şeklinde aktarılabilir. PCR tabanlı sgRNA aktarımı özel sgRNA dizisini U6 promotör şablonunu yükseltmek için kullanılan reverse PCR primerin içine ekler. Bu yöntem çok sayıda aday sgRNA'nın süratle taranması için idealdir çünkü fonksiyonel test için hücre transfeksiyonları sgRNA'yı kodlayan primerler elde edildikten kısa bir süre sonra yapılabilir. sgRNA kodlayan primerler 100 bç'den büyüktür. Bu yöntem büyük knock-out kütüphanelerinin oluşturulması için birçok ko-transfeksiyonlayıcı sgRNA'nın testi ya da diğer ölçek duyarlı uygulamalar için kullanılabilir. sgRNA için ekspresyon plazmidinin 
oluşturulması da basit ve hızlıdır. $\mathrm{Bu}$ işlem kısmi komplementer bir çift oligonükleotid ile tek bir klonlama basamağını içerir. 20-nt kılavuz sekansını kodlayan oligo çiftleri plazmide aktarılır. Transfeksiyon plazmidler aynı zamanda in vivo aktarım için virüs üretimini sağlamak amacı ile modifiye edilebilir. PCR ve plazmid bazlı aktarma yöntemlerine ek olarak, Cas9 ve sgRNA sırasıyla mRNA ve RNA gibi hücreler içine direk aktarılabilir (Ran ve ark., 2013).

\section{Onarım Şablonunun Tasarımı}

Hedefli DNA modifikasyonlar, değişim bölgesini kuşatan homoloji kollarını içeren plazmid tabanlı verici tamir şablonlarının kullanımına gereksinim duymaktadır (Smithies ve ark., 1985). Her bölgenin homoloji kolları kendi içinde değişim göstermektedir fakat genellikle bu bölgeler 500 bç’den büyüktürler. Bu yöntem florasan proteinler ya da antibiyotik direnç markörleri gibi raportör genlerin aktarımını da içeren büyük modifikasyonların oluşturulmasında kullanılabilmektedir (Wu ve ark., 2008).

\section{Hücrelerin Klonal İzolasyonu}

Bazen özel modifikasyonlara sahip klonal hücrelerin izolasyonuna gereksinim duyulmaktadır. $\mathrm{Bu}$ izolasyon floresans ile aktive olan hücre tasnifi ya da birkaç seyreltme ve takibinde yeni klonal hücrelerin oluşması için gelişme evresiyle gerçekleştirilebilir. Ancak, hücre tiplerinin tek hücre izolasyonuna verdikleri tepki önemli oranda farklılık gösterebilir. Hedef hücreler ile ilgili literatüre bakılmalıdır (Ran ve ark., 2013).

\section{Fonksiyonel Test}

Hücrelerde meydana getirilmiş genetik modifikasyonlar SURVEYOR ${ }^{\circledR}$ nükleaz yöntemi ya da dizileme ile bulunabilir (Guschin ve ark., 2010). SURVEYOR ya da dizileme primerleri genomik DNA'dan ilgili bölgeyi çoğaltmak için manuel olarak tasarlanabilir. SURVEYOR primerleri jel elektroforez bantlarının temiz görüntülenmesi için Cas9'un hedef bölgesinin 200 ila 400 bç'lik herhangi bir yarısını çoğaltacak şekilde tasarlanmalıdır. Primer dimerlerinin oluşumunu engellemek için SURVEYOR primerleri 18 ila $25 \mathrm{nt}$ uzunluğunda ve erime sıcaklıkları $60{ }^{\circ} \mathrm{C}$ civarında olacak şekilde tasarlanmalıdır (Ran ve ark., 2013).

\section{Hayvanlarda Yapılan Çalışmalar}

Wang ve ark. (2015) keçiler üzerinde yaptıkları çalışmalarında, tek hücre safhasındaki embriyolara MSTN ve FGF5 fonksiyonel genlerini hedefleyen Cas9 mRNA ve sgRNA'larının enjeksiyonu ile bir ya da iki geni değişime uğramış oğlaklar elde etmişlerdir. Her iki gen için birincil fibroblastta hedefleme verimliliği \%60 olarak tespit etmişlerdir. Test ettikleri 98 hayvanda hedefleme verimliğini MSTN geni modifikasyonu için \%15, FGF5 geni modifikasyonu için \%21 ve her iki genin aynı anda modifikasyonu içinde \%10 olarak tespit etmişlerdir. Elde ettikleri veriler 1 şı̆̆ında CRISPR/Cas9 sistemi ile büyük hayvanlarda birden çok gen bölgesinin modifikasyonunun gerçekleştirilebileceğini ve bu sistemin önümüzdeki yıllarda hayvan 1slahında çok büyük bir paya sahip olacağını belirtmişlerdir.
Young ve ark. (2015) fareler üzerinde yaptıkları çalışmalarında, erkek farelerin sperm kuyruklarının yapısına etki eden Dnaic1, Wdr63 ve Ccdc63 genlerini hedef alan CRISPR/Cas9 sistemini uygulamışlardır. Bu genler testislerde yüksek derecede ifadelenmektedir. Yaptıkları analizlerin sonucunda Dnaic1 ve Wdr63 genlerinin erkek üreme kabiliyeti üzerinde bir etkisinin olmadığı fakat Ccdc63 geninin susturulması farelerin spermlerinin kuyruklarının kısalması sebebiyle kısır kalmalarına sebep olduğunu bildirmişlerdir. Bu çalıșmanın sonucunda CRISPR/Cas9 sistemi kullanılarak hayvanların yüksek derecede karışık sistemlerinde modifkasyonların kolaylıkla yapılabileceğini belirtmişlerdir.

Yin ve ark. (2014), insan hepatositlerinde Fah geni üzerinde gerçekleşen mutasyonlar ile ortaya çıkan kalıtsal tirosinami üzerinde fareleri model alarak yaptıkları çalışmalarında; Cas9 ve sgRNA kombinasyonunu içeren plazmid ile ssDNA kalıbını hidrodinamik kuyruk enjeksiyonu yöntemini kullanarak farelere aktarmışlar ve canlı ağırlık kaybına sebep olan fenotipi ortadan kaldırmışlardır. Çalışma sonucunda elde ettikleri veriler 1şığında CRISPR/Cas9 sisteminin hayvanlarda genom modifikasyonunda kullanılabileceğini bildirmişlerdir.

Farelerin PCSK9 (Convertase Subtilisin/Kexin Type 9) geni üzerinde meydana gelen mutasyonlar, düşük yoğunluklu lipoprotein kolesterol seviyesinde azalmaya ve buna bağlı olarak kardiyovasküler sorunlara sebep olmaktadır. Ding ve ark. (2014) farelerde bu durumu CRISPR/Cas9 sistemi ile elimine etmeyi hedefledikleri çalışmalarında, PCSK9 geninin ilk ekzonunu hedefleyen Cas9 ve sgRNA'yı fare karaciğerine adenovirüs vektörüyle aktarmışlardır. Karaciğer hücrelerinin \%50'sinin modifiye edildiğini, hepatik düşük yoğunluklu lipoprotein kolesterol seviyelerinde artış olduğunu, kolesterol seviyelerinde $\% 30$ ile $\% 40$ arasında azalma olduğunu ve hiçbir hedef dişı mutasyona rastlanmadığını gözlemlemişlerdir (Ding ve ark., 2014).

Xue ve ark. (2014), yabani farelerde kanser üzerine yaptıkları çalışmalarında fare karaciğerinde bulunan Pten ve P53 tümör baskılayıcı genlerini hedefleyen sgRNA'y1 ve Cas9'u ifadeleyen DNA kalıbını içeren plazmidi hidrodinamik enjeksiyon ile karaciğere aktarmışlar; \%20 oranında hepatosit modifikasyon ve karaciğer tümörlerinde azalma gözlemlediklerini bildirmişlerdir.

\section{Değerlendirmeler}

CRISPR/Cas9 sisteminin türler arası gen transferi sistemlerinden farklı olarak organizmanın genetik yapısında zaten var olan potansiyelin ortaya çıkarılması esasına dayanması bu sistemin toplum tarafindan daha kolay kabullenilmesini sağlayacaktır. $\mathrm{Bu}$ sistemle ilgili güncel çalışmalar özellikle insan sağlığı konusunda önem taşıyan belirli genetik kökenli kusurlar üzerine odaklanmış durumdadır. Bunun temel nedenlerinden biri bu teknolojinin geliştirilme amaçlarının başında insan sağlığına dönük iyileştirme potansiyelinin yüksekliği ve umut vericiliğinin gelmesidir. Bununla birlikte özellikle kompleks organizmalarda gen ifadesinin düzenlenmesi ile ilgili süreçlerin karmaşıklığı, bu yöntemle düzeltilmeye çalışan olumsuzlukların şimdilik sadece basit kalıtsal modellere sahip gen bölgeleriyle kısıtlı kalmasına neden olmaktadır. 
Günümüzde CRISPR/Cas9 sistemi hayvanlarda basit ve etkili bir gen düzenleme mekanizması olarak görülmektedir. Ancak, CRISPR/Cas9 sisteminin optimizasyonunda hali hazırda üstesinden gelinmesi gereken önemli sorunlar vardır. Bunların başında sistemin gen hedefleme aralığının ve özgünlüğünün arttırılması gelmektedir. Ayrıca, CRISPR/Cas9 sistemi bileşenlerinin ve bunların ifadelenmesinin hücre tiplerine ve canlı türlerine göre optimize edilmesi de önemli görülmektedir. Önündeki sorunların aşılması durumunda CRISPR/Cas9 sisteminin, kalıtsal kökenli hastalıklar ve fonksiyonel genomik üzerine yapılacak çalışmalara önemli katkı yapacağı düşünülmektedir.

CRISPR/Cas9 sisteminde kat edilen her basamak teknolojiyi bir adım ileriye taşımaktadır fakat teknoloji geliştikçe konu hakkında ki etik endişelerde artmaktadır. Bunlardan en önemlisi bu teknolojinin canlıların eşey hücrelerini manipüle etmede kullanılabilme potansiyelidir. Bu sebep ile bu teknoloji kullanırken çok dikkatli olunmalıdır. Hedeflenen genin bütün fonksiyonları ortaya çıkarılmamış ise bu geni susturmanın ya da ifadelenmesini sağlanmasının bir sonraki generasyonda nasıl etkiler ortaya çıkaracağı öngörülememektedir.

CRISPR/Cas9 sisteminin ileride bir gen düzenleme mekanizması olmaktan çıkıp bir gen terapisi mekanizması haline gelebilme potansiyeli bulunmaktadır. $\mathrm{Bu}$ sistem, tek bir gen mutasyonundan çoklu gen düzenlemelerine, genom modifikasyonlarından kanser ve diyabet gibi kompleks genetik hastalıklar ile mücadeleye kadar gelecekte birçok alanda kullanılabilecektir. Ayrıca CRISPR/Cas9 sistemi mutasyon kombinasyonlarının etkisinin, basit gen susturulmaları ile görülemeyen gen fonksiyonlarının ve kodlama yapmayan dizilerin etkilerinin incelenmesine de imkân vereceği öngörülmektedir.

\section{Hayvan Islahı Açısından Sunduğu Firsatlar}

Çiftlik hayvanlarında ekonomik olarak önemli özelliklerin poligenik kalıtım göstermesi bu özellikleri determine eden gen sayısına bağlı olarak CRISPR/Cas9 sisteminin etkinliğini de sınırlayabilir. Yöntemin, henüz model organizmalar üzerinde ve sinırlı sayıda gen bakımından deneniyor olmasına rağmen, karakterleri etkileyen genler ve bunların düzenleme mekanizmaları daha iyi anlaşıldıkça gelecekte çiftlik hayvanlarında önemli özellikler bakımından yapılacak ıslah çalışmaları açısından firsatlar sağlayacağı düşünülmektedir.

Hayvan ıslahında karşılaşılan temel sorunlardan biri ekonomik olarak önemli özellikleri kontrol eden gen bölgeleri arasındaki negatif korelasyonların varlığıdır. Örneğin sığırlarda et verimi ile süt verimi arasında, tavuklarda yaşama gücü ile yumurta verimi arasında ya da hastalıklara dayanıklılık ile hemen tüm diğer verim özellikleri arasındaki bu negatif ilişkinin varlığı uzun yıllardır bilinmektedir. CRISPR/Cas9 sisteminin kullanımıyla negatif korelasyonlara sahip özelliklerin birlikte 1slahı da mümkün olabilecektir. Hayvan 1slahı açısından köklü değişikliklere yol açma potansiyeli nedeniyle bu sistemin, yakın gelecekte daha çok üzerinde durulması ve araştırılması gereken konulardan biri olacağ düşünülmektedir. Ülkemizde yapılan hayvan 1slahı çalışmalarında bu teknolojinin sunduğu firsatlardan da yararlanma olanaklarının araştırılması konusunda geri kalınmaması gerekmektedir.

\section{Kaynaklar}

Barrangou R, Fremaux C, Deveau H, Richards M, Boyaval P, Moineau S, Romero DA, Horvath P. 2007. CRISPR provides acquired resistance against viruses in prokaryotes. Science 315: 1709-1712.

Cho SW, Kim S, Kim JM, Kim JS. 2013. Targeted genome engineering in human cells with the Cas9 RNA-guided endonuclease. Nat. Biotechnol. 31: 230-232.

Cong L, Ran FA, Cox D, Lin S, Barretto R, Habib N, Hsu PD, Wu X, Jiang W, Marraffini LA, Zhang F. 2013. Multiplex genome engineering using CRISPR/Cas systems. Science 339: 819-823.

Ding Q, Strong A, Patel KM, Ng SL, Gosis BS, Regan SN, Cowan CA, Rader DJ, Musunuru, K. 2014. Permanent alteration of PCSK9 with in vivo CRISPR-Cas9 genome editing. Circulation Research 115(5): 488-492..

Eisler MC, Lee MRF. 2014. Steps to sustainable livestock. Nature 507: 32-34

Garneau, JE, Dupuis M, Villion M, Romero DA, Barrangou R, Boyaval P, Fremaux C, Horvath P, Magadán AH, Moineau S. 2010. The CRISPR/Cas bacterial immune system cleaves bacteriophage and plasmid DNA. Nature 468: 67-71.

Guschin DY, Waite AJ, Katibah GE, Miller JC, Holmes MC, Rebar EJ. 2010. A rapid and general assay for monitoring endogenous gene modification. Methods Mol. Biol. 649: $247-256$.

Hackett PB, Alvarez MC. 2000. The molecular genetics of transgenic fish. Recent Advances in Marine Biotechnology 4: $77-145$.

Hackett PB, Fahrenkrug SC, Carlson DF. 2014. The Promises and Challenges of Precision Gene Editing in Animals of Agricultural Importance. North American Agricultural Biotechnology Council Report 26: 39-45.

Hoekstra AY, Wiedmann TO. 2014. Humanity's unsustainable environmental footprint. Science 344: 1114-1117.

Oliveira TY, Resch W, Jankovic M, Casellas R, Nussenzweig MC, Klein IA. 2012. Translocation capture sequencing: a method for high throughput mapping of chromosomal rearrangements. J. Immunol. Methods 375: 176-181.

Ran FA, Hsu PD, Wright J, Agarwala V, Scott DA, Zhang F. 2013. Genome engineering using the CRISPR-Cas9 system. Nature Protocols 8: 2281-2308.

Sanjana NE, Cong L, Zhou Y, Cunniff MM, Feng G, Zhang F. 2012. A transcription activator-like effector toolbox for genome engineering. Nat. Protoc. 7: 171-192.

Smithies O, Gregg RG, Boggs SS, Koralewski MA, Kucherlapati RS. 1985. Insertion of DNA sequences into the human chromosomal globin locus by homologous recombination. Nature 317: 230-234.

Vince G. 2014. Adventures in the Anthropocene: A Journey to the Heart of the Planet We Made. London: Chatto\& Windus.

Wang H, Yang H, Shivalila CS, Dawlaty MM, Cheng AW, Zhang F, Jaenisch R. 2013. One-step generation of mice carrying mutations in multiple genes by CRISPR/Casmediated genome engineering. Cell 153: 910-918.

Wang X, Yu H, Lei A, Zhou J, Zeng W, Zhu H, Dong Z, Niu Y, Shi B, Cai B, Liu J, Huang S, Yan H, Zhao X, Zhou G, He X, Chen X, Yang Y, Jiang Y, Shi L, Tian X, Wang Y, Ma B, Huang X, Qu L, Chen Y. 2015. Generation of genemodified goats targeting MSTN and FGF5 via zygote injection of CRISPR/Cas9 system. Scientific Reports 5: 13878, DOI: 10.1038/srep13878. 
Wu S, Ying GX, Wu Q, Capecchi MR. 2008. A protocol for constructing gene targeting vectors: generating knockout mice for the cadherin family and beyond. Nat. Protoc. 3: $1056-1076$.

Xue W, Chen S, Yin H, Tammela T, Papagiannakopoulos T, Joshi NS, Cai W, Yang G, Bronson R, Crowley DG, Zhang F, Anderson DG, Sharp PA, Jacks T. 2014. CRISPRmediated direct mutation of cancer genes in the mouse liver. Nature 514(7522): 380-384.
Yin H, Xue W, Chen S, Bogorad RL, Benedetti E, Grompe M, Koteliansky V, Sharp PA, Jacks T, Anderson DG. 2014. Genome editing with Cas9 in adult mice corrects a disease mutation and phenotype. Nature Biotechnol. 32(6): 551-553.

Young SA, Miyata H, Satouh Y, Kato H, Nozawa K, Isotani A, Aitken RJ, Baker MA, Ikawa M. 2015. CRISPR/Cas9Mediated Rapid Generation of Multiple Mouse Lines Identified Ccdc63 as Essential for Spermiogenesis. Int. J. Mol. Sci. $16: 24732-24750$. 